\title{
IGF-I receptor activation and BCL-2 overexpression prevent early apoptotic events in human neuroblastoma
}

\author{
CM van Golen ${ }^{1}$, VP Castle ${ }^{2}$ and EL Feldman ${ }^{\star, 1}$ \\ ${ }^{1}$ Department of Neurology and Neuroscience Program, University of Michigan, \\ Ann Arbor, Michigan, USA \\ ${ }^{2}$ Department of Pediatrics and Communicable Diseases, University of Michigan, \\ Ann Arbor, Michigan, USA \\ * Corresponding author: EL Feldman, University of Michigan, Department of \\ Neurology, 200 Zina Pitcher Place, 4414 Kresge III, Ann Arbor, MI 48109- \\ 0588, USA. Tel: 734-763-7274; Fax: 734-763-7275; \\ E-mail: efeldman@umich.edu
}

Received 29.10.99; revised 22.2.00; accepted 6.3.00

Edited by CJ Thiele

\begin{abstract}
The type I insulin-like growth factor receptor (IGF-IR) is important for mitogenesis, transformation, and survival of tumor cells. The current study examines the effect of IGF-IR expression and activation on apoptosis in SHEP human neuroblastoma cells. SHEP cells undergo apoptosis which is prevented by IGF-I addition or overexpression of the IGF-IR (SHEP/IGF-IR cells). High mannitol treatment activates caspase- 3 by $1 \mathrm{~h}$ in SHEP cells while caspase- 3 activation is delayed by $3 \mathrm{~h}$ in SHEP/IGF-IR cells. Transfection with Bcl-2 (SHEP/Bcl-2 cells) prevents serum withdrawal and mannitol induced apoptosis and caspase-3 activation. Mannitol induces mitochondrial membrane depolarization in both SHEP and SHEP/IGF-IR cells. IGF-IR activation or overexpression of Bcl-2 in SHEP cells prevents mitochondrial membrane depolarization. Collectively, these results suggest that IGF-IR or Bcl-2 overexpression in neuroblastoma cells promotes cell survival by preventing mitochondrial membrane depolarization and caspase-3 activation, ultimately leading to increased tumor growth. Cell Death and Differentiation (2000) 7, 654-665.
\end{abstract}

Keywords: caspase; mitochondria; mannitol; SHEP; IGF-IR

Abbreviations: DMEM, Dulbecco's Modified Eagle's Medium; ERK, extracellular related kinase; IGF, insulin-like growth factor; IGF-IR, Type I IGF receptor; IGF-IIR, Type II IGF receptor; JNK, jun kinase; MAPK, mitogen activated protein kinase; PI-3K, phosphatidylinositol 3-kinase; SDS-PAGE, sodium dodecyl sulfatepolyacrylamide gel electrophoresis; S.E.M., standard error of the mean

\section{Introduction}

Neuroblastoma is a sympathetic nervous system tumor derived from primordial neural crest cells and accounts for $8-10 \%$ of all childhood solid tumors. ${ }^{1-4}$ Neuroblastoma can spontaneously regress, but progressive tumors remain untreatable by current chemotherapeutic and radiation therapy regimens. ${ }^{1}$ The deletion of the short arm of chromosome 1 and $\mathrm{N}$-myc amplification are the only two consistent genetic changes seen in neuroblastoma. ${ }^{2}$ Growth factors, including the neurotrophins and the insulin-like growth factor (IGF) family, are likely involved in neuroblastoma progression and resistance to treatment. ${ }^{2,3,5}$

The IGF-I family consists of two polypeptides, IGF-I and IGF-II, the type I and type II receptors (IGF-IR and IGF-IIR), and the IGF binding proteins. ${ }^{6}$ The biological actions of IGF ligands are mediated through the IGF-IR and include mitogenesis, transformation, and protection from apoptosis. ${ }^{7}$ Each of these actions are mediated by a different portion of the receptor, shown through mutational analyses, and likely requires different downstream targets to produce an effect. ${ }^{8-12}$ IGF-I, IGF-II, and the IGF-IR are expressed in a wide variety of tumor types, including neuroblastoma. ${ }^{3}$ IGF-IR activation enhances neuroblastoma cell proliferation and survival, and increased IGF-IR expression increases the protection of neuroblastoma cells from apoptosis induced by chemotherapeutic agents and mannitol treatment. ${ }^{13}$

Upon binding of IGF ligands to the IGF-IR, the IGF-IR is autophosphorylated and recruits the adaptor proteins IRS-1 and Shc. ${ }^{14}$ These adaptor proteins then recruit further binding partners to activate two major downstream signaling pathways: the mitogen activated protein kinases (MAPKs) (which include the extracellular related kinases (ERKs), the jun kinases (JNKs) and p38) and the phosphatidyinositol-3 kinase (PI-3K) pathway. ${ }^{15,16}$ The predominant pathway involved in IGF-I mediated protection of cells from apoptosis is the PI-3K pathway. ${ }^{17-20}$ One of the principal downstream effectors of the $\mathrm{PI}-3 \mathrm{~K}$ pathway which mediates cell survival is the serine/threonine kinase Akt. ${ }^{21,22}$

The IGF system can affect members of two families of apoptosis regulatory proteins, the $\mathrm{Bcl}-2$ family and the caspases. ${ }^{23,24}$ The Bcl-2 family consists of many members, both pro-apoptotic and anti-apoptotic. ${ }^{23} \mathrm{Bcl}-2$ and $\mathrm{Bcl}-\mathrm{X}_{\mathrm{L}}$ are localized to the outer mitochondrial membrane and are thought to regulate channel pores in the mitochondrial membrane, controlling the release of factors which promote apoptosis such as apoptosis inducing factor (AIF) and cytochrome $c^{25-27} \mathrm{Bcl}-2$ and $\mathrm{Bcl}-\mathrm{X}_{\mathrm{L}}$ expression are increased in several neuroblastoma cell lines and primary tumors $^{28,29}$ resulting in increased survival and chemoresistance. IGF-IR activation can maintain $\mathrm{Bcl}-2$ and $\mathrm{Bcl}-\mathrm{X}_{\mathrm{L}}$ protein expression in high mannitol conditions which normally induce apoptosis in neuroblastoma cells. ${ }^{30}$

The caspases are a family of cysteine proteases which preferentially cleave substrates at aspartate residues. There are currently 11 identified members of the caspase family ${ }^{31}$ which can be loosely placed into one of two 
groups: the activator and the effector caspases. Caspases are activated when the holoenzyme is cleaved to release the prodomain from the active enzyme. ${ }^{32}$ Blocking caspase activity in many cell types prevents apoptosis. ${ }^{33-35}$ The most downstream effector caspase, caspase-3, is essential for apoptosis to occur in many systems. ${ }^{36,37}$ IGF-IR activation can prevent the cleavage of caspase-3 and caspase-7 in both SH-SY5Y and SHEP neuroblastoma cells. Prevention of hyperosmotic-induced caspase activation by IGF-IR and subsequent protection from apoptosis occurs via the PI-3K in a Bcl-dependent mechanism. ${ }^{13,30,38}$

The current study addresses the effects of IGF-IR activation and $\mathrm{Bcl}-2$ expression on apoptotic events in SHEP human neuroblastoma cells. IGF-IR expression alone can delay mannitol-mediated caspase activation and prevent apoptosis induced by serum withdrawal in SHEP neuroblastoma cells. The cells are protected from mannitol induced apoptosis regardless of receptor number when IGF is present in the media, and caspase- 3 is not cleaved. SHEP cells transfected with $\mathrm{Bcl}-2$ are completely protected from both serum withdrawal and hyperosmotic induced apoptosis. Caspase-3 cleavage is also prevented by $\mathrm{Bcl}-2$ overexpression.

Hyperosmotic stress also elicits mitochondrial changes in SHEP neuroblastoma cells. Changes in mitochondrial membrane depolarization are not seen at early time points, suggesting that caspase-3 activation occurs prior to this event in hyperosmotic-induced apoptosis. However, mannitol causes dose dependent mitochondrial membrane depolarization in SHEP and SHEP/IGF-IR cells at a later time point, and this depolarization is prevented by the addition of IGF-I. SHEP/Bcl-2 cells show no mitochondrial membrane depolarization in the presence of high doses of mannitol. These results suggest that IGF-I promotes neuroblastoma tumorigenesis in part by blocking mitochondrial membrane depolarization and protecting cells from apoptosis through caspase-3 and Bcl-2 dependent mechanisms.

\section{Results \\ IGF-I prevents apoptosis in SHEP neuroblastoma cells}

The SHEP human neuroblastoma cell line was subcloned from SK-N-SH. SHEP cells have little IGF-IR, ${ }^{13,40}$ cannot form colonies in soft agar or tumors in nude mice, and requires serum for growth. ${ }^{41}$ First, the effect of IGF-I on apoptosis was examined in SHEP cells under hyperosmotic conditions. Cells were exposed to increasing concentrations of mannitol with or without IGF-I. Even in the absence of mannitol, over $30 \%$ of the cells are apoptotic after $24 \mathrm{~h}$, suggesting that serum withdrawal alone induces apoptosis in SHEP cells. The number of apoptotic cells increases to over $60 \%$ in $300 \mathrm{mM}$ mannitol (Figure 1), indicating significant additional apoptosis does not occur until the media is very hyperosmotic. Upon addition of $10 \mathrm{nM}$ IGF-I to the media, more than $50 \%$ of the cells are rescued from both serum-withdrawal and hyperosmotic-induced apoptosis (Figure 1). All conditions in which IGF-I was added are statistically significant from the corresponding experimental

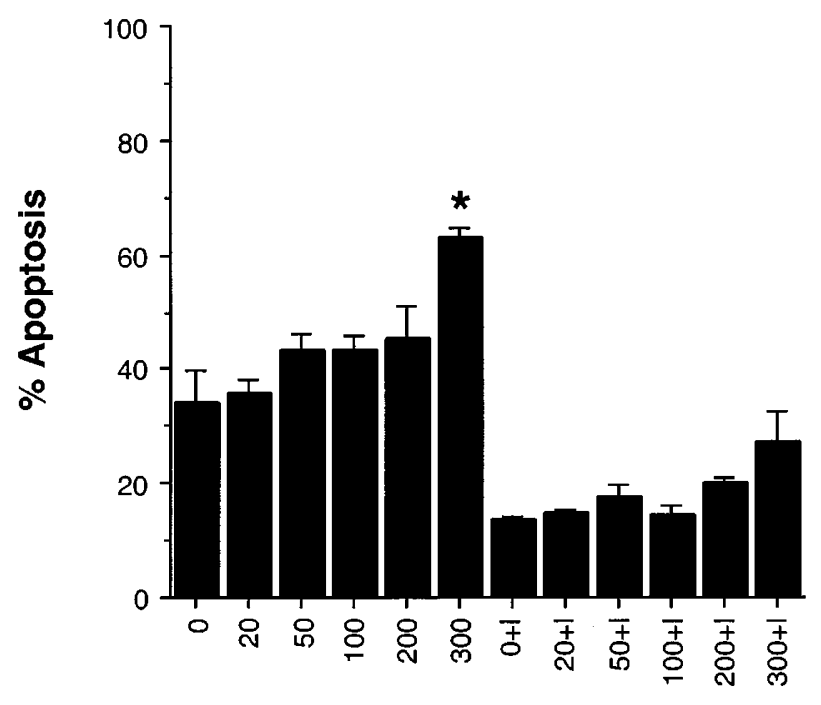

\section{Condition}

Figure 1 IGF-I prevents serum withdrawal and hyperosmotic-induced apoptosis in SHEP neuroblastoma cells. Serum deprived SHEP cells were exposed to $0,20,50,100,200$, and $300 \mathrm{mM}$ mannitol $\pm 10 \mathrm{nM} \mathrm{IGF}-\mathrm{I}$ (I) for $24 \mathrm{~h}$. Cells were then collected and prepared for flow cytometry. Results shown are the mean+S.E.M. for three separate experiments. An * means the value was statistically different from DMEM alone $(P<0.01)$. All conditions containing IGF-I were statistically significant compared with the corresponding non-IGF-I condition

condition lacking IGF-I. Although SHEP cells do express low levels of the IGF-IR, the receptors present are functional. ${ }^{40}$ Considering the low amount of IGF-IR expression in normal SHEP cells, this implies that very little IGF-IR is necessary for protection of neuroblastoma cells from apoptosis.

To further demonstrate the ability of IGF-I to rescue SHEP cells from apoptosis, bisbenzimide staining was performed. SHEP cells in isotonic media (DMEM alone) display few pyknotic nuclei. Although DNA fragmentation is detected by flow cytometry at $24 \mathrm{~h}$ in cells in DMEM alone, morphological changes in the nuclei of these cells as examined by light microscopy are not seen. When cells are exposed to $300 \mathrm{mM}$ mannitol, there is a decrease in overall cell density and many fragmented nuclei are seen, indicative of cells which had already completed the apoptotic process (Figure 2a). However, IGF-I addition to the media prevents morphological changes associated with apoptosis and prevents the loss in cell density seen in hyperosmotic conditions (Figure $2 \mathrm{~b}$ ).

Caspase-3 is the most downstream caspase and caspase cleavage is necessary for apoptosis to occur in many systems. ${ }^{36,37}$ Upon activation, caspase-3 is cleaved from the $32 \mathrm{kD}$ proenzyme into 17 and $14 \mathrm{kD}$ fragments. Therefore, caspase-3 cleavage was investigated in SHEP cells as another measure of apoptosis. Cells were exposed to $300 \mathrm{mM}$ mannitol for 1 to $12 \mathrm{~h}$. Western blot analysis shows the presence of the 17 and $14 \mathrm{kD}$ activation bands after $1 \mathrm{~h}$ of hyperosmotic exposure (Figure 3a), which continues through $12 \mathrm{~h}$. SHEP cells were then exposed to 

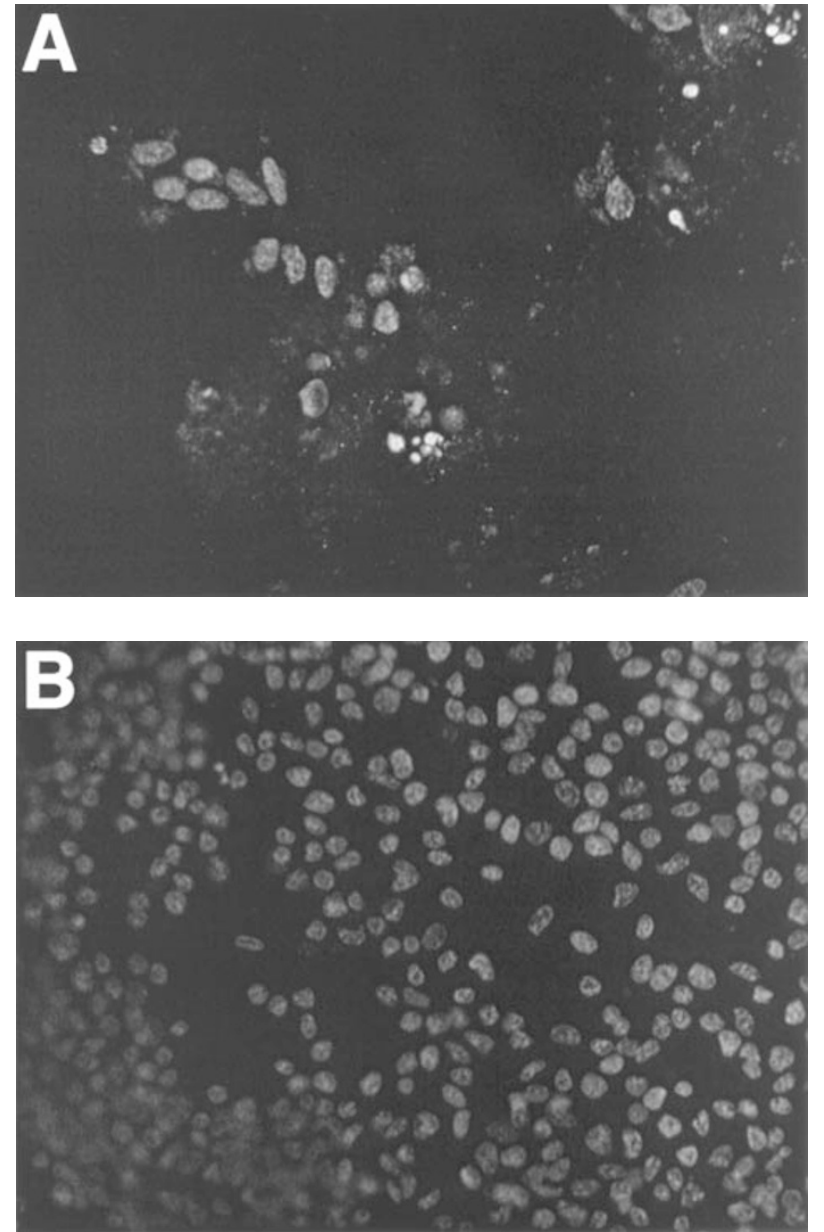

Figure 2 IGF-I prevents hyperosmotic-induced morphological changes in SHEP cells. Serum deprived SHEP cells were exposed to (a) $300 \mathrm{mM}$ mannito and (b) $300 \mathrm{mM}$ mannitol+10 nM IGF-I. After $24 \mathrm{~h}$, cells were fixed, rinsed, and stained with bisbenzimide. Representative fields are shown for each condition

hyperosmotic media in the presence or absence of $10 \mathrm{nM}$ IGF-I. IGF-I prevents the cleavage of caspase-3 at both 3 and $6 \mathrm{~h}$ after mannitol exposure (Figure $3 \mathrm{~b}$ ). These data demonstrate once again the potent protective effect of IGFI, even in cells expressing little IGF-IR

\section{IGF-IR overexpression prevents apoptosis induced by serum withdrawal and delays caspase-3 activation}

SHEP cells were previously transfected with varying levels of IGF-IR to determine the effect of IGF-IR expression on mitogenesis and resistance to cell death. ${ }^{13}$ When SHEP cells are transfected with the IGF-IR, serum withdrawal alone does not induce apoptosis. In DMEM alone, about $35 \%$ of normal untransfected SHEP cells are apoptotic (Figure 1). In contrast, only $10 \%$ of SHEP/IGF-IR cells are apoptotic in serum-free media (Figure 4a). The number of apoptotic SHEP/IGF-IR cells increases with increasing hyperosmolar conditions, with over $75 \%$ of the cells apoptotic at $300 \mathrm{mM}$ mannitol. IGF-I rescues a little over

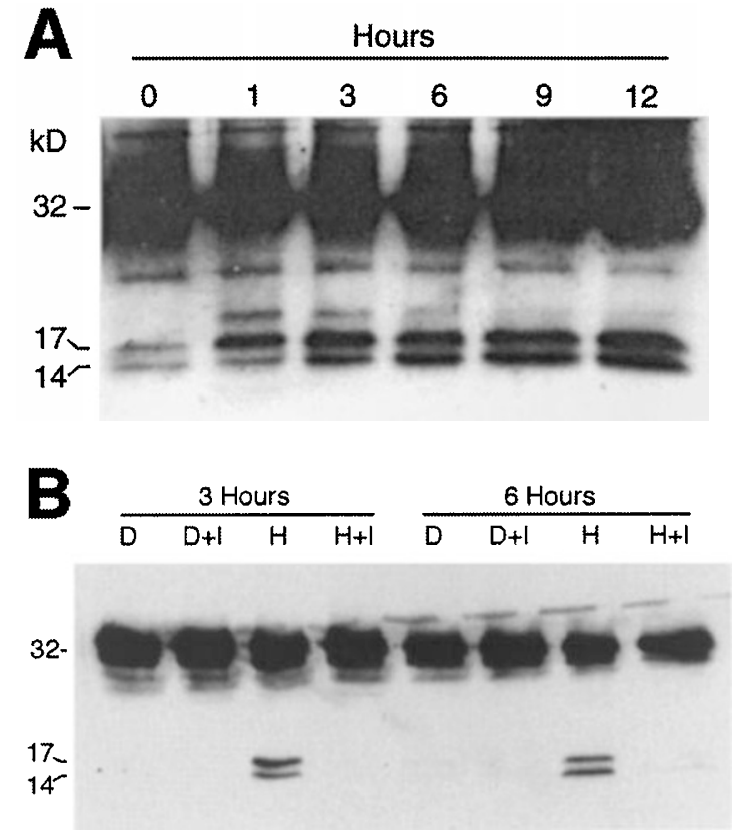

Figure 3 (a) Caspase-3 is activated after hyperosmotic exposure in SHEP cells. Cells were serum deprived for $4 \mathrm{~h}$, then treated with $300 \mathrm{mM}$ mannitol. At $0,1,3,6,9$, and $12 \mathrm{~h}$, whole cell lysates were collected and Western immunoblotting performed for caspase-3. Blot shown is one of three performed. (b) IGF-I prevents hyperosmotic-induced caspase-3 activation in SHEP cells. Serum deprived cells were exposed to DMEM, DMEM+10 nM IGFI, $300 \mathrm{mM}$ mannitol, or $300 \mathrm{mM}$ mannitol+10 nM IGF-I. At 3 and $6 \mathrm{~h}$, whole cell lysates were collected and Western immunoblotting performed for caspase-3. Blot shown is one of three performed

$50 \%$ of the cells at each concentration (Figure $4 \mathrm{a}$ ), which is statistically significant for all mannitol concentrations tested. These data show that transfection of the IGF-IR alone protects SHEP cells from serum withdrawal induced apoptosis.

We then investigated activation of two of the principal pathways downstream from the IGF-IR, Akt and MAP kinase, in the SHEP and SHEP/IGF-IR cells (Figure 4b). In untransfected SHEP cells, Akt and Erk1/Erk2 were phosphorylated upon stimulation with IGF-I for $30 \mathrm{~min}$, once again confirming the activation of the IGF-IR in SHEP cells, despite the low number of receptors present. In SHEP/IGF-IR cells however, both signaling proteins were phosphorylated to a greater extent upon stimulation with IGF-I than were the parental SHEP cells, as is expected with increased expression of the IGF-IR. Interestingly, in SHEP/IGF-IR cells, Akt and Erk1/Erk2 were also phosphorylated in the absence of IGF-I, indicating autophosphorylation without ligand. Therefore, IGF-IR overexpression likely protects SHEP cells from serum withdrawal induced apoptosis through a low basal activation of the IGF-IR and downstream signaling cascades in the absence of ligand stimulation.

Caspase-3 activation was examined in whole cell lysates collected from SHEP/IGF-IR cells exposed to hyperosmotic conditions for time periods from 1 to $12 \mathrm{~h}$. In normal SHEP cells, caspase- 3 activation is detected using Western blot analysis by $1 \mathrm{~h}$ post-mannitol exposure (Figure 3a). 


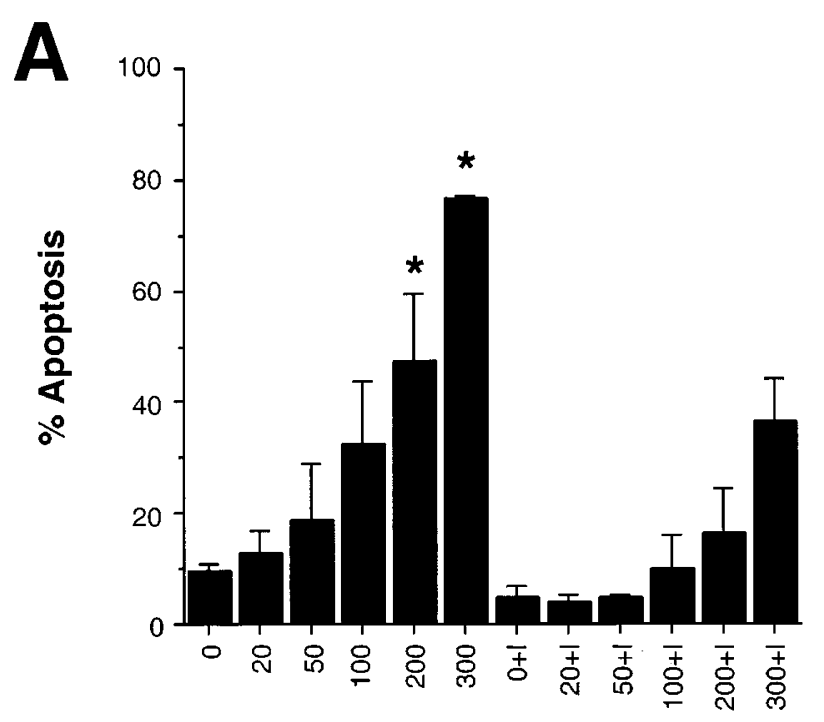

Condition

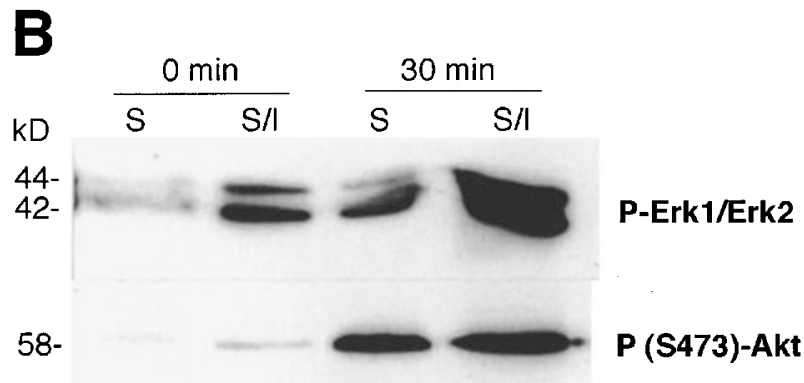

Figure 4 (a) IGF-IR overexpression prevents serum withdrawal induced apoptosis in SHEP cells. SHEP/IGF-IR cells were serum deprived for $4 \mathrm{~h}$, treated with $0,20,50,100,200$, or $300 \mathrm{mM}$ mannitol $\pm 10 \mathrm{nM}$ IGF-I (I) for $24 \mathrm{~h}$, then prepared for flow cytometry. Results shown are the mean+S.E.M. for three separate experiments. An * indicates the value is statistically significant $(P<0.01)$ from DMEM alone. All IGF-I conditions were statistically significant from the corresponding non-IGF-I condition. (b) IGF-IR overexpression increases phosphorylation of Akt and Erk1/Erk2 in SHEP cells. SHEP (S) and SHEP/IGF-IR (S/I) cells were serum deprived for $4 \mathrm{~h}$, treated with DMEM (D) $\pm I G F-I$ (I) for 0 or $30 \mathrm{~min}$. Whole cell lysates were collected with RIPA buffer, separated on an SDS-PAGE gel, transferred to nitrocellulose, and immunoblotted for the indicated protein

However, caspase-3 activation does not occur in SHEP/IGFIR cells until $3 \mathrm{~h}$ of exposure to hyperosmotic conditions (Figure 5a). To further support this finding, fluorometric caspase- 3 activity assays were performed. The peak shifts in fluorescence, indicating peak caspase-3 activity, are present at $45 \mathrm{~min}$ in normal SHEP cells. In contrast, the peak shifts in fluorescence are delayed until $3 \mathrm{~h}$ in SHEP/ IGF-IR cells (Figure 5b). These data indicate that IGF-IR overexpression can delay caspase-3 activation induced by hyperosmotic exposure in SHEP neuroblastoma cells.

Given the effect of IGF-IR overexpression on caspase-3 activation in SHEP cells, we next examined the effect of blocking caspase-3 activation using an effector caspase inhibitor, bok-asp-fmk, on hyperosmotic induced apoptosis in these cells (Figure 5c). Upon exposure of SHEP/IGF-IR cells to $300 \mathrm{mM}$ mannitol for $24 \mathrm{~h}, 50 \%$ of the cells became apoptotic as previously reported. In the presence of IGF-I, only $16 \%$ of SHEP/IGF-IR cells were apoptotic in high mannitol conditions. When SHEP/IGF-IR cells are incubated with bok-asp-fmk, $26 \%$ of the cells become apoptotic in hyperosmotic media. In the presence of both IGF-I and bok-asp-fmk, only $8.7 \%$ of SHEP/IGF-IR cells undergo hyperosmotic-induced apoptosis. Together, these data suggest that although IGF-I primarily prevents apoptosis in a caspase- 3 mediated process, IGF-I may also prevent a portion of the cells from undergoing apoptosis in a noncaspase mediated manner.

SHEP cells transfected with the IGF-IR in the reverse orientation (FC-4 cells), which would prevent the formation of endogenous functional IGF-IR protein, ${ }^{13}$ not only showed control levels of apoptosis at low concentrations of mannitol, but also increased sensitivity to a hyperosmotic environment at higher mannitol concentrations (Figure 6). At higher mannitol concentrations, $45-60 \%$ of SHEP cells were apoptotic and $75-85 \%$ of $\mathrm{FC}-4$ cells were apoptotic. In the presence of IGF-I, more FC-4 cells were apoptotic compared to SHEP/IGF-IR cells (Figure 1) at all mannitol concentrations tested (Figure 6). In untransfected SHEP cells and SHEP/IGF-IR cells, over $50 \%$ of the cells are rescued by IGF-I. In the FC-4 cells however, IGF-I only rescues about $25 \%$ of the cells in high mannitol conditions, and IGF-I does not protect the cells in low mannitol conditions. This implies that transfection of IGF-IR in the reverse orientation is preventing endogenous IGF-IR from exerting a protective effect.

\section{Bcl-2 overexpression prevents apoptosis in SHEP neuroblastoma cells}

IGF-IR activation can regulate the expression of $\mathrm{Bcl}-2$ in $\mathrm{SH}-$ SY5Y neuroblastoma cells, suggesting that IGF-I neuroprotection is mediated in part by the Bcl-2 family of proteins. ${ }^{30}$ To support a role for $\mathrm{Bcl}-2$ in preventing apoptosis in neuroblastoma, SHEP cells, which normally do not express Bcl$2,{ }^{28,39}$ were stably transfected with this protein. ${ }^{39}$ As shown previously, when normal SHEP cells are exposed to hyperosmotic media, about $60 \%$ of the cells undergo apoptosis as measured by flow cytometry of propidium iodide stained cells. Approximately half of these cells are rescued by the addition of IGF-I to the media (Figure 1). In contrast, SHEP/Bcl-2 cells show only $2-4 \%$ apoptotic cells in response to hyperosmotic media with or without IGF-I addition after $24 \mathrm{~h}$ (Figure 7a). This demonstrates a profound effect of $\mathrm{Bcl}-2$ in protecting these cells against an apoptotic stimulus.

To further support this finding, lysates from SHEP/Bcl-2 cells were collected 1-4 days after hyperosmotic exposure and examined for caspase-3 cleavage. Little caspase-3 cleavage is detected, even after 4 days of exposure to hyperosmotic conditions (Figure $7 \mathrm{~b}$ ). Because SHEP cells are normally serum dependent, ${ }^{40}$ therefore we would expect substantial apoptosis in SHEP cells maintained in DMEM alone after a period of 4 days. However, no caspase-3 cleavage is detected (Figure 7b), and no detached cells are seen, suggesting viable cells in serumfree conditions over this period of time. 


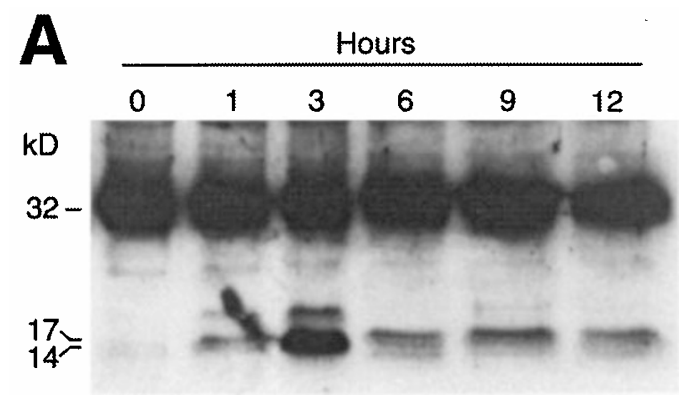

B

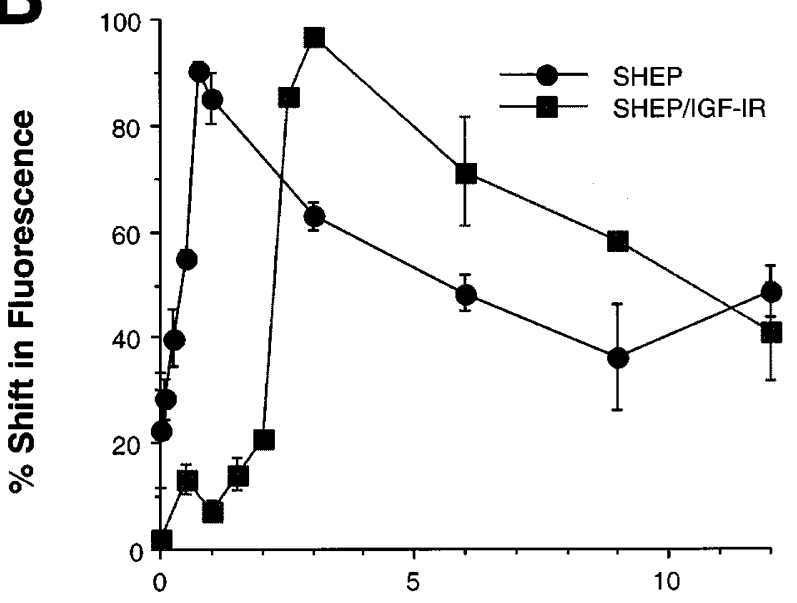

Time
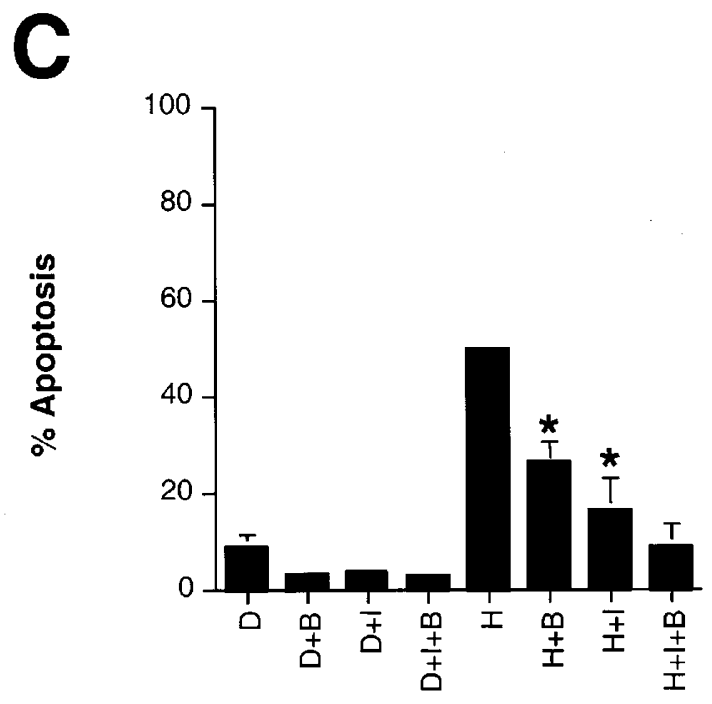

\section{Condition}

Figure 5 (a) Caspase-3 activation is delayed in SHEP/IGF-IR cells. Serum deprived SHEP/IGF-IR cells were exposed to $300 \mathrm{mM}$ mannitol. At 0, 1, 3, 6, 9 , and $12 \mathrm{~h}$, whole cell lysates were collected and Western immunoblotting performed for caspase-3. Result shown is one of three experiments performed. Detection of bands at 17 and $14 \mathrm{kD}$ indicate caspase-3 cleavage. (b) Peak caspase-3 enzyme activity occurs earlier in SHEP cells than SHEP/IGF-IR cells. Serum deprived SHEP cells were exposed to $300 \mathrm{mM}$ mannitol for $0,0.25,0.5,0.75,1,3,6,9,12,18$, and $24 \mathrm{~h}$. Serum deprived SHEP/IGF-IR cells were exposed to $300 \mathrm{mM}$ mannitol for $0,0.5,1,1.5,2,2.5$, $3,6,9,12,18$, and $24 \mathrm{~h}$. Cells were collected and caspase-3 activity was

\section{IGF-I prevents mitochondrial membrane depolarization in SHEP and SHEP/IGF-IR cells}

Bcl-2 exerts its effects primarily at the endoplasmic reticulum and the mitochondria. ${ }^{42}$ Events occurring at the mitochondria have a profound effect on apoptosis in many cell types. ${ }^{26,43,44}$ Because Bcl-2 overexpression prevented hyperosmoticinduced apoptosis and caspase-3 cleavage in SHEP cells, we reasoned that changes in the mitochondrial membrane potential may serve as an early marker of neuroblastoma apoptosis. Depolarization of the mitochondrial membrane was measured using Rh123 in SHEP and SHEP/IGF-IR cells at 1, 3 , and $6 \mathrm{~h}$, time points coincident with caspase- 3 activation in these cells. In DMEM alone and DMEM+10 nM IGF-I, the mitochondrial membrane potential is essentially the same in both cell types at all time points tested (data not shown). In hyperosmotic conditions, untransfected SHEP cells show a slight increase in the number of cells with a depolarized membrane by $6 \mathrm{~h}$, but this increase is not statistically significant when compared to cells maintained in DMEM alone (Figure 8a). Therefore, a later time point, $18 \mathrm{~h}$, was

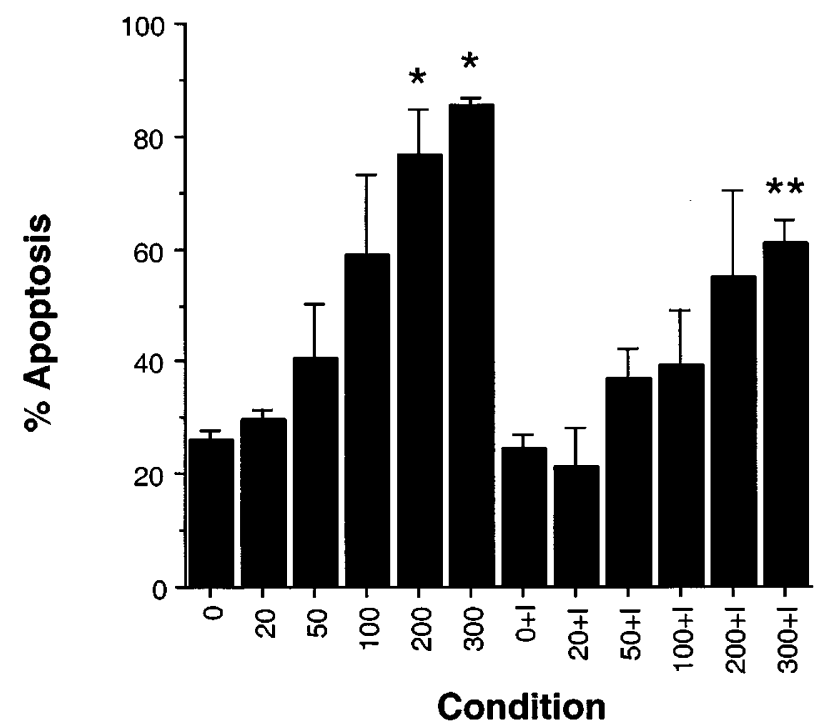

Figure 6 Transfection of IGF-IR in the reverse orientation hinders IGF-IR protection from apoptosis in SHEP cells. FC-4 cells were serum deprived $4 \mathrm{~h}$, treated with $0,20,50,100,200$, or $300 \mathrm{mM}$ mannitol $\pm 10 \mathrm{nM}$ IGF-I (I) for $24 \mathrm{~h}$, then collected for flow cytometry. Results shown are the mean+S.E.M. for three separate experiments. An * represents a result statistically significant compared with DMEM alone. $A$ ** represents a result statistically significant compared with the corresponding non-IGF-I condition

measured using the fluorometric kit as previously described. An increase in fluorescence indicates increased caspase-3 enzyme activity. (c) Bok-asp-fmk prevents hyperosmotic-induced apoptosis in SHEP/IGF-IR cells. Serum deprived SHEP cells were exposed to DMEM (D) $\pm 300 \mathrm{mM}$ Mannitol (H) $\pm 10 \mathrm{nM}$ IGF-I (I) $\pm 50 \mu \mathrm{M}$ Bok-asp-fmk (B). Cells were collected $24 \mathrm{~h}$ later with trypsinization, then prepared for flow cytometry. Results shown are the mean+S.E.M. for three separate experiments. S.E.M. is included in all conditions, but too small to detect graphically in several conditions. An* represents results statistically significant from hyperosmotic condition 
A
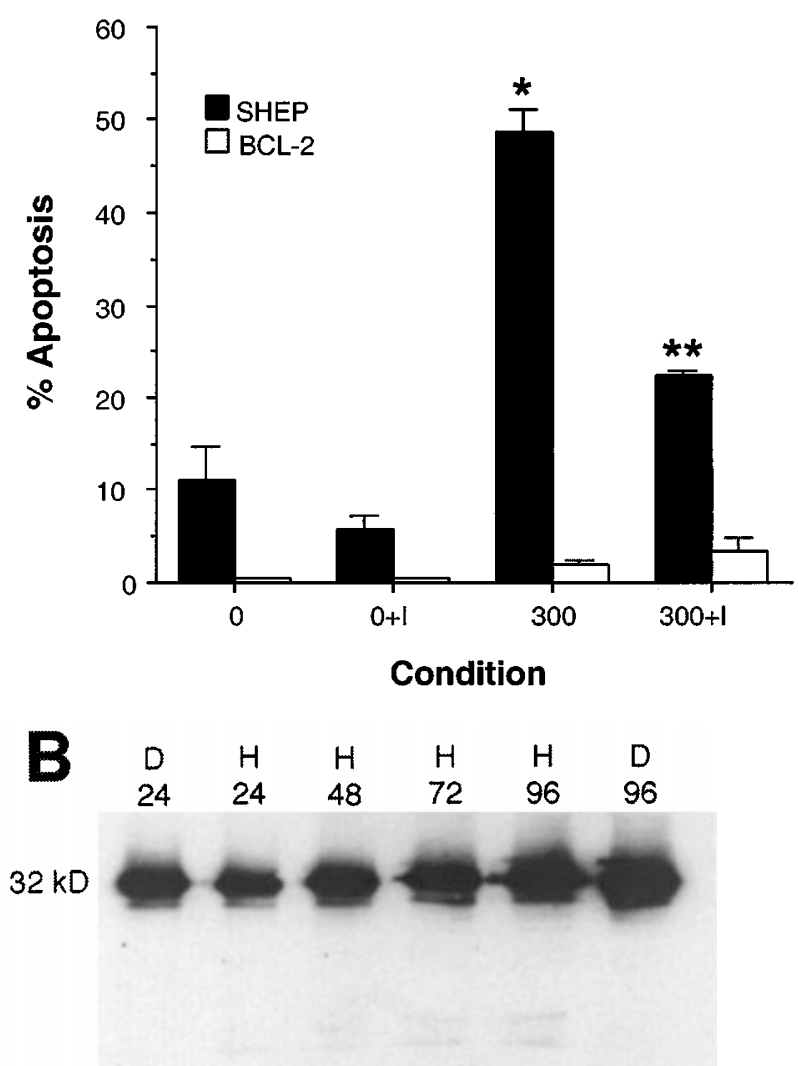

Figure 7 (a) Bcl-2 overexpression prevents apoptosis in SHEP human neuroblastoma cells. SHEP or SHEP/Bcl-2 cells were exposed to DMEM (D) $\pm 10 \mathrm{nM}$ IGF-I (I) or $300 \mathrm{mM}$ mannitol (H) \pm IGF-I. After $24 \mathrm{~h}$, cells were collected and prepared for flow cytometry. Results shown are mean \pm S.E.M. for three separate experiments. An ${ }^{*}$ signifies statistical significance when compared with DMEM alone $(P<0.01)$. A ${ }^{* *}$ means the results were statistically significant $(P<0.01)$ compared with $300 \mathrm{mM}$ mannitol alone. (b) $\mathrm{Bcl}-2$ overexpression prevents caspase-3 activation in SHEP neuroblastoma cells. Cells were exposed to DMEM (D) or $300 \mathrm{mM}$ mannitol (H). At 24, 48, 72, and $96 \mathrm{~h}$, whole cell lysates were collected and run on an SDS-PAGE gel. Western immunoblotting was performed for caspase-3. Result shown is one of three experiments performed. Detection of bands at 17 and $14 \mathrm{kD}$ indicate caspase-3 cleavage

used to determine if significant changes in mitochondrial membrane potentials occur with mannitol treatment. Normal SHEP cells (Figure $8 b$ ) and SHEP/IGF-IR cells (Figure $8 c$ ) were treated with increasing concentrations of mannitol with or without IGF-I followed by incubation with Rh123 to examine mitochondrial membrane potential. In both cell lines at $18 \mathrm{~h}$, the number of cells with depolarized mitochondria increases in mannitol conditions, and this mitochondrial membrane depolarization is prevented by IGF-I. In SHEP/IGF-IR cells exposed to IGF-I, the number of cells with increased Rh123 fluorescence is even less than control, implying increased protection over that seen in SHEP cells (Figure 8c).

$\mathrm{SHEP} / \mathrm{Bcl}-2$ cells were also examined for the response of the mitochondria to hyperosmotic exposure. SHEP/Bcl-2 cells were exposed to $300 \mathrm{mM}$ mannitol $\pm 10 \mathrm{nM}$ IGF-I for the same early time points examined above (1, 3 and $6 \mathrm{~h}$ ).
Virtually no change in Rh123 fluorescence was detected, suggesting no change in the mitochondrial membrane potential (Figure 9a). When SHEP/Bcl-2 cells were exposed to increasing concentrations of mannitol at the later $18 \mathrm{~h}$ time point, less than $5 \%$ of the viable cells showed mitochondrial membrane depolarization (Figure $9 b)$, indicating a complete protection of the mitochondria from hyperosmotic-induced mitochondrial membrane depolarization. Taken together, these data suggest that IGF-I acts upstream from the mitochondria and may exert its protective effect in part by preventing mitochondrial membrane depolarization, either directly or indirectly, through a $\mathrm{Bcl}$ protein-dependent mechanism.

\section{Discussion}

The IGF family plays a role in tumorigenesis. The IGFs and the IGF-IR are expressed in many primary tumors ${ }^{45}$ and tumor cell lines. ${ }^{46}$ IGF signaling though the IGF-IR is important for protecting tumor cells from apoptosis. ${ }^{13,47-49}$ Antibodies against IGF-IR, antisense strategies against IGF-I and IGFIR, and dominant negative IGF-IR mutants all reduce cell survival and promote cell death. ${ }^{50-52}$ Conversely, overexpression of IGF-IR enhances cell survival in response to death signals ${ }^{13,53,54}$ and IGF-I, via interaction with IGF-IR, can prevent apoptosis. ${ }^{55-57}$ IGFs can also alter the drug sensitivity of cancer cells, rendering them resistant to chemotherapy induced apoptosis. ${ }^{58-60}$

In the current study, we examined the role the IGF system plays in neuroblastoma, a pediatric tumor of the peripheral nervous system. We have previously shown that hyperosmotic exposure induces apoptosis in SHEP neuroblastoma cells. ${ }^{13}$ In this study, we found a significant portion of SHEP cells become apoptotic after serum withdrawal, and the number of apoptotic cells only increases after high doses of mannitol. Serum withdrawal induces apoptosis in many neuronal cell types. In cerebellar granule cells, serum withdrawal potentiates apoptosis induced by potassium withdrawal, with less than $50 \%$ viable cells after $30 \mathrm{~h} .{ }^{61}$ Serum and potassium deprivation also increase caspase- 3 activity and caspase3 mRNA levels in cerebellar granule cells. ${ }^{62}$ Removal of serum induces apoptosis in hippocampal neuron populations as well within $6 \mathrm{~h} .{ }^{63}$ Several neuroblastoma cell lines undergo apoptosis upon serum-withdrawal, including NG108 cells, ${ }^{64}$ NB 2 a cells, ${ }^{65}$ and SK-N-BE cells. ${ }^{66}$

IGF-I rescues several cell types from serum withdrawal induced apoptosis, including HBL100 human breast cancer cells, ${ }^{58} \mathrm{H} 9 \mathrm{C} 2$ cardiac muscle cells, ${ }^{67}$ differentiated $\mathrm{PC}-12$ cells, ${ }^{68}$ and dorsal root ganglion neurons. ${ }^{69}$ In SHEP cells, IGF-I rescued over $50 \%$ of the cells from apoptosis in all conditions, despite the low levels of IGF-IR present in SHEP cells. ${ }^{13}$ Although SHEP cells have little IGF-IR, the IGF-IR present is functional and activates downstream signaling pathways $\left[{ }^{40}\right.$, Figure $4 \mathrm{~b}$, this study]. These downstream signaling cascades can then protect the cells from hyperosmotic-induced apoptosis despite low receptor numbers.

IGF-I appears to act upstream from the caspases. In SHEP cells, caspase-3 activation occurs within $1 \mathrm{~h}$ of 
A

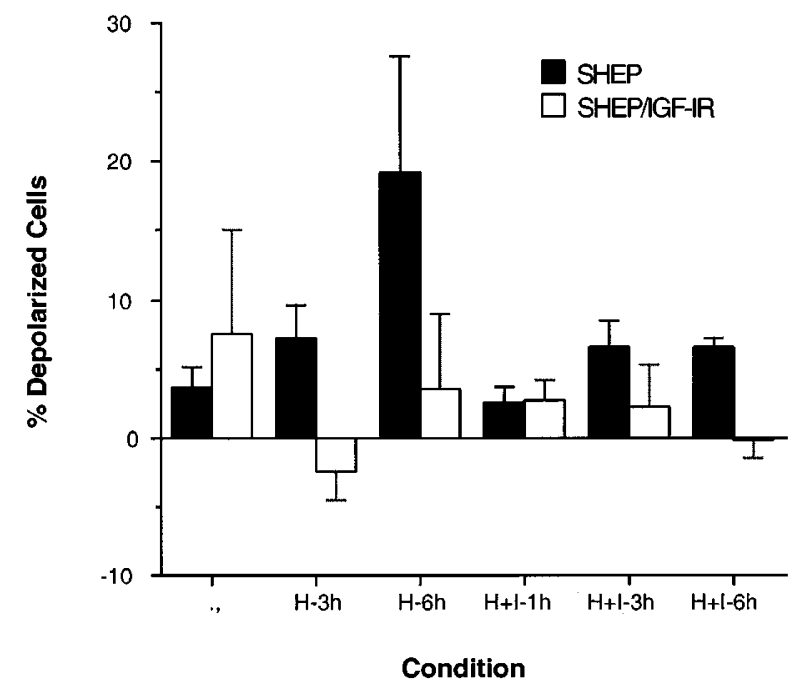

B

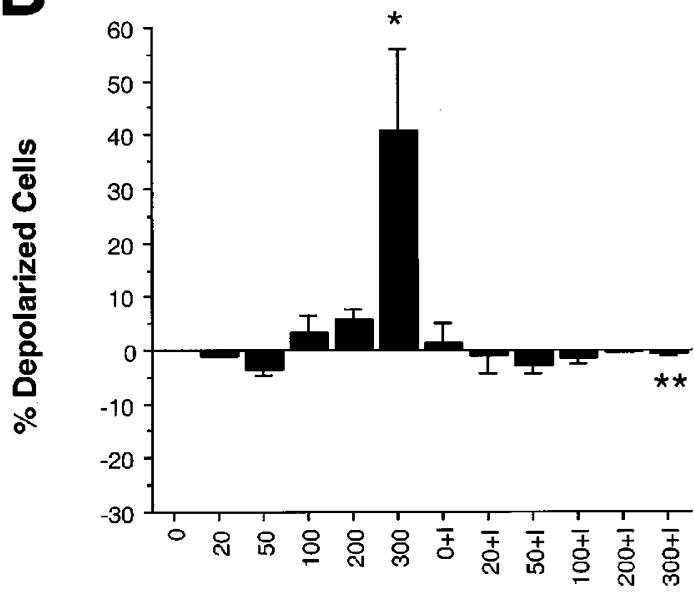

Condition

C

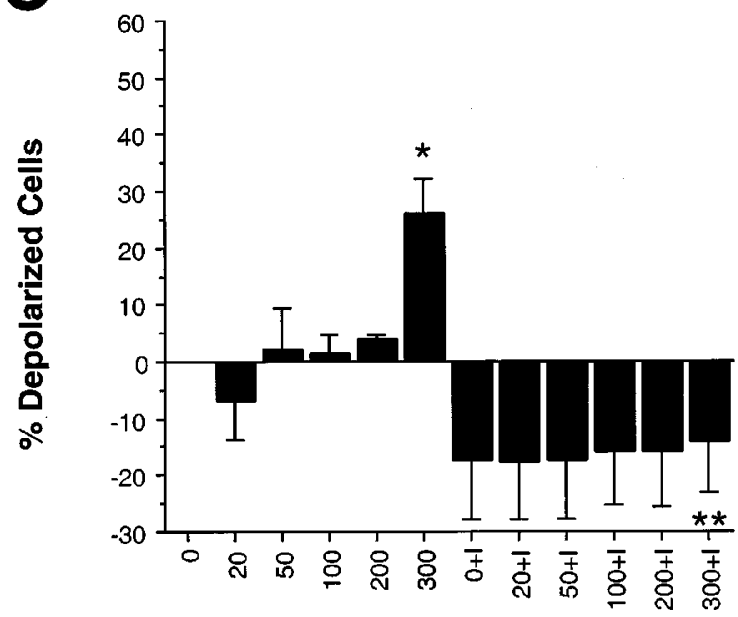

Condition
A

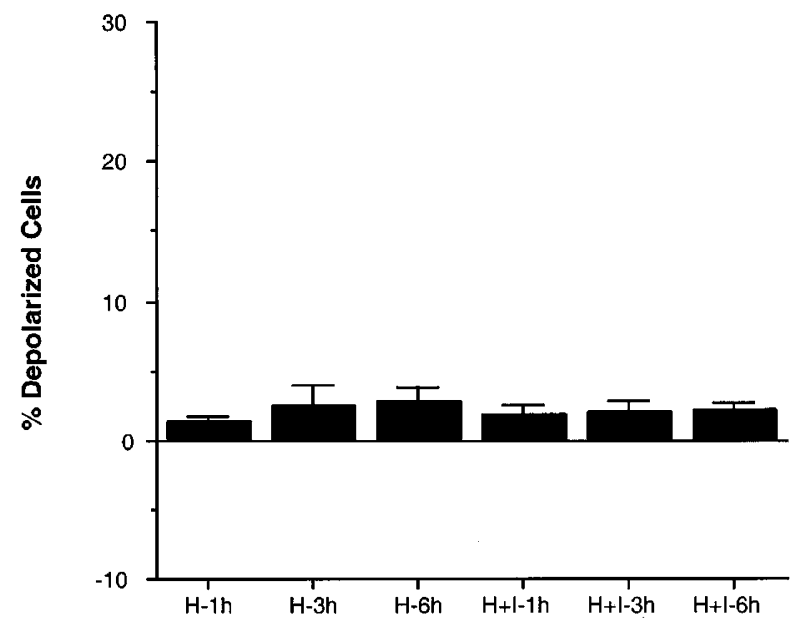

Condition

B

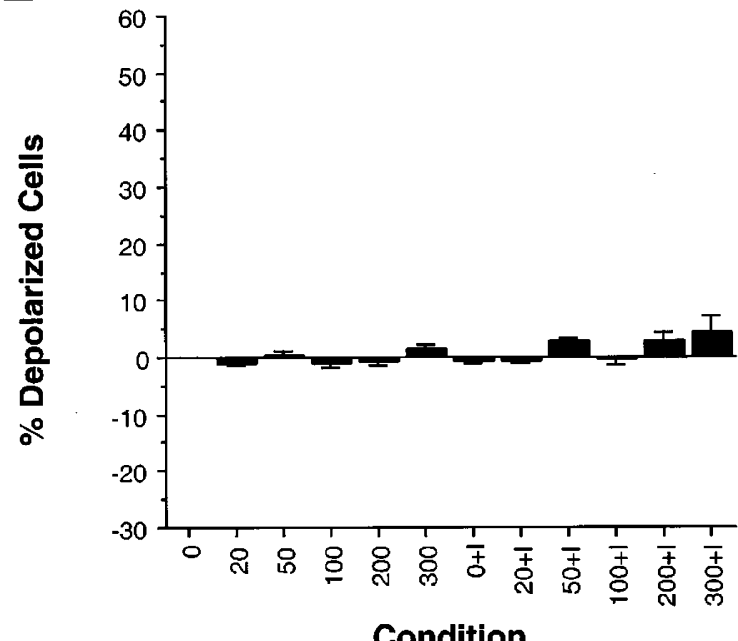

Figure $9 \mathrm{Bcl}-2$ overexpression prevents mitochondrial membrane depolarization in SHEP cells. (a) SHEP/Bcl-2 cells were exposed to $300 \mathrm{mM}$ mannitol $(\mathrm{H}) \pm 10 \mathrm{nM}$ IGF-I (I) for $0,1,3$, or $6 \mathrm{~h}$. Cells were then prepared for Rh123 analysis. Results shown are mean+S.E.M. for three separate experiments. No values were statistically different from control. (b) SHEP/Bcl-2 cells were serum deprived and treated with $0,20,50,100,200$, or $300 \mathrm{mM}$ mannitol $\pm 10 \mathrm{nM}$ IGF-I (I) for $18 \mathrm{~h}$. Cells were then prepared for Rh123 analysis. Results shown are mean+S.E.M. for three separate experiments. No values were statistically significant compared with control

Figure 8 IGF-I prevents hyperosmotic-induced mitochondrial membrane depolarization in SHEP and SHEP/IGF-IR cells. (a) Serum deprived SHEP (S) or SHEP/IGF-IR (S/I) cells were exposed to $300 \mathrm{mM}$ mannitol $(\mathrm{H})+10 \mathrm{nM}$ IGF-I (I) for $0,1,3$, or $6 \mathrm{~h}$. Cells were then prepared for Rh123 analysis. Results shown are the mean+S.E.M. for three independent experiments. No values were statistically significant from control. Serum deprived (b) SHEP or (c) SHEP/IGF-IR cells were exposed to $0,20,50,100,200$, or $300 \mathrm{mM}$ mannitol $\pm 10 \mathrm{nM}$ IGF-I for $18 \mathrm{~h}$. Cells were then prepared for Rh123 analysis. Results shown are mean+S.E.M. for three separate experiments. $A n$ * means the results are statistically different from DMEM alone. $A$ ** means the results are statistically significant compared with the corresponding nonIGF-I condition 
mannitol exposure, and caspase-3 activation was prevented by IGF-I addition. Caspase-3 activation occurs in response to drug treatment in several neuroblastoma cell lines. SH-SY5Y cells, which were subcloned from the same parental line as the SHEP cells used in this study, show caspase- 3 cleavage in response to staurosporine by $3 \mathrm{~h},{ }^{70}$ and by $6 \mathrm{~h}$ in response to mannitol treatment. ${ }^{38} \mathrm{In} \mathrm{SH}$ SY5Y cells, caspase-3 activation also occurs in response to nitric oxide, ${ }^{71}$ hypoxia/hypoglycemia, or excitotoxin exposure. $^{72}$

The IGF-IR is postulated to play a role in the progression of several tumor types. ${ }^{73}$ IGF-IR is overexpressed in most breast cancer cell lines, and IGF-IR autophosphorylation and tyrosine kinase activity correlate with breast malignancy. ${ }^{74}$ Inhibition of IGF-IR expression causes neuroblastoma tumor regression in mice, and this regression is through the induction of apoptosis. ${ }^{75} \mathrm{We}$ have previously shown that transfection of SHEP cells with the IGF-IR transforms the cells and decreases their susceptibility to apoptosis induced by mannitol or etoposide treatment. ${ }^{13}$ In the current study, IGF-IR overexpression prevents apoptosis induced by serum withdrawal and delays caspase-3 activation. In support of our findings, overexpression of the IGF-IR enhances survival of Rat-I fibroblasts exposed to dimethylformamide ${ }^{76}$ and myocytes after infarction. ${ }^{77}$ In addition, mutational analysis shows distinct regions of the IGF-IR mediate mitogenesis, transformation, and cell survival. ${ }^{10-12}$ Since about $50 \%$ of SHEP and SHEP/IGF-IR cells are rescued in high mannitol conditions in response to IGF-I, the protection of SHEP/IGF-IR cells from serum withdrawal induced apoptosis may be due to the transformation of these cells by IGF-IR transfection rather than by increased IGF-I sensitivity.

In SHEP/IGF-IR cells, phosphorylation of two downstream signaling molecules, Akt and Erk1/Erk2, was increased over that seen in SHEP parental cells upon exposure to IGF-I ligand. This result was expected given the high expression of the IGF-IR. ${ }^{13}$ In parallel Akt and Erk1/Erk2 were also phosphorylated in the absence of IGFI ligand. This likely explains how overexpression of the IGFIR protects SHEP neuroblastoma cells from serum withdrawal induced apoptosis without IGF-I ligand present. The IGF-IR is potentially autophosphorylated when overexpressed, producing autoactivation, leading to activation of downstream signaling molecules mediating cell survival. In human breast cancer, cells taken from malignant tumors as opposed to normal cells showed IGF-IR phosphorylation and kinase activity 2-3-fold higher than control cells in the absence of IGF ligand. ${ }^{74}$ In MCF-7 breast cancer cells, overexpression of the IGF-IR increased cell-cell adhesion and the formation of aggregates as well, which in and of itself enhances proliferation and cell survival, even though sensitivity to IGF-I ligand was not enhanced. ${ }^{78}$ Therefore, these two studies, in addition to our own, suggest the possibility that tumor cells with increased IGF-IR expression may be protected from apoptosis induction through either autophosphorylation of the receptor or upregulation of other protective proteins, leading to tumor cell survival in the absence of growth factors.
$\mathrm{Bcl}-2$ is an anti-apoptotic protein found in both tumor ${ }^{79}$ and normal cell populations, such as neurons. ${ }^{80}$ We have previously reported that mannitol treatment decreases Bcl-2 protein expression in SH-SY5Y neuroblastoma cells. ${ }^{30} \mathrm{We}$ therefore compared the ability of hyperosmotic stress to induce apoptosis in SHEP cells, which do not express Bcl2 , and SHEP cells overexpressing Bcl-2 (SHEP/Bcl-2). Bcl2 overexpression completely blocked caspase-3 activation and apoptosis induced by serum withdrawal or hyperosmotic stress. Similar findings are reported in GT1-7 neuronal cells where serum withdrawal and drug induced apoptosis is prevented by $\mathrm{Bcl}-2$, which normally acts upstream from the caspases. ${ }^{81} \mathrm{~A}$ rat colon carcinoma cell line, which normally yields regressive tumors, is also protected from serum withdrawal induced apoptosis by Bcl-2 transfection. $^{82}$ These $\mathrm{Bcl}-2$ overexpressing clones produced metastatic, lethal tumors. ${ }^{82}$ Finally, in SHEP neuroblastoma cells, Bcl-2 overexpression prevents apoptosis induced by cisplatin or etoposide. ${ }^{39}$

The exact role for $\mathrm{Bcl}-2$ in protecting against apoptosis is under investigation. $\mathrm{Bcl}-\mathrm{X}_{\mathrm{L}}$, a protein highly homologous to $\mathrm{Bcl}-2$, is thought to regulate a channel pore in the outer mitochondrial membrane through which apoptosis inducing factors, such as AIF or cytochrome $c$, are released into the cytoplasm to activate the caspase cascade. ${ }^{42}$ This hypothesis is based on the similarity of the threedimensional structure of $\mathrm{BCl}-\mathrm{X}_{\mathrm{L}}$ to pore-forming domains of bacterial toxins, such as diphtheria toxin and poreforming colicins, and the ability of overexpression of $\mathrm{Bcl}-\mathrm{X}_{\mathrm{L}}$ to effect the release of cytochrome $c$ into the cytoplasm. ${ }^{42}$ $\mathrm{BCl}-\mathrm{X}_{\mathrm{L}}$ can also form a channel when it is inserted into synthetic lipid membranes. ${ }^{27}$ A similar role has been postulated for a Bcl-2 channel. ${ }^{25,83,84} \mathrm{Bcl}-2$ can bind to the permeability transition pore complex, thereby preventing permeability transition and subsequent mitochondrial membrane depolarization. ${ }^{43,44}$

Given the role of $\mathrm{Bcl}-2$ and mitochondrial events in apoptosis, we investigated the effect of IGF-I, IGF-IR, and $\mathrm{Bcl}-2$ expression on mitochondrial membrane depolarization in SHEP cells. Early time points were chosen first since the predominant hypothesis regarding the mitochondria and effector caspase activation places mitochondrial membrane depolarization and cytochrome $c$ release before downstream caspase activation. However, essentially no changes in mitochondrial membrane potential were detected in SHEP cells by $6 \mathrm{~h}$ of mannitol exposure. These data suggest that in hyperosmotic-induced apoptosis in SHEP cells, caspase-3 activation occurs first in a mitochondria-independent mechanism. Mannitol induces mitochondrial membrane depolarization in SHEP cells in about $45 \%$ of the cells at $18 \mathrm{~h}$, and this depolarization is blocked by the addition of IGF-I to the media or by Bcl-2 overexpression. IGF-IR transfection of SHEP cells had little effect on mitochondrial membrane potential changes in this experimental paradigm.

Mitochondrial membrane potential is affected by Fas induction in Jurkat cells, by IL-3 withdrawal in FL5.12 cells, ${ }^{26}$ and by doxorubicin and betulinic acid in SHEP neuroblastoma cells. ${ }^{85}$ In each of these cases, Bcl-2 or Bcl$\mathrm{X}_{\mathrm{L}}$ prevent mitochondrial membrane depolarization; how- 
ever, in these systems, disruption of mitochondrial membrane potential precedes caspase-3 activation. In contrast, caspase- 3 activation occurs prior to mitochondrial membrane depolarization in staurosporine treated Jurkat cells; in this experimental paradigm, cytochrome $c$ release and caspase- 3 activation occur concomitantly and prior to mitochondrial membrane potential loss. ${ }^{86}$ UVB irradiation or staurosporine treatment of HeLa cells also caused cytochrome $c$ translocation to the cytosol followed by caspase-3 activation, and inhibition of caspases by zVAD.fmk prevented mitochondrial membrane depolarization but not cytochrome $c$ translocation. ${ }^{87}$ Staurosporine treatment induces cytochrome $c$ release by $1 \mathrm{~h}$ and caspase- 3 activation by $2 \mathrm{~h}$ in SH-SY5Y neuroblastoma cells, and both of these events occur even in the presence of the mitochondrial permeability transition inhibitors bongkrekic acid and cyclosporin $\mathrm{A}^{88}$ When SH-SY5Y neuroblastoma cells are treated with caspase-3 inhibitors, the mitochondrial membrane potential is maintained in the presence of high glucose, a stimulus which normally causes mitochondrial membrane depolarization (James Russell, personal communication). This suggests that mitochondrial membrane depolarization lies downstream from effector caspase activation in glucose-mediated death of neuroblastoma cells as well.

Although the mechanism of early cytochrome $c$ release is unknown, recent reports show that Bax translocation to the mitochondria can induce cytochrome $c$ translocation to the cytosol in HeLa cells and SH-SY5Y cells. ${ }^{88,89}$ Bax can induce cytochrome $c$ release from isolated mitochondria within $30 \mathrm{~min}$ without mitochondrial permeability transition. $^{89,90}$ In cell free systems, cytochrome $c$ is released spontaneously and leads to caspase- 3 cleavage without a loss of mitochondrial membrane potential. ${ }^{91}$ Taken together, these studies suggest that cytochrome $c$ can be released without mitochondrial permeability transition, potentially through a Bax-dependent mechanism. Cytochrome $c$ can then activate caspase-3 within the time frame seen in this study. Active caspase- 3 can also accelerate cytochrome $c$ release in a cell free system. ${ }^{92}$ Therefore, caspase-3 could then feed back to the mitochondria, eventually causing mitochondrial permeability transition which finally leads to a loss of mitochondrial membrane potential. Further studies will address the validity of this potential mechanism in hyperosmotic-induced apoptosis in neuroblastoma cells.

In summary, IGF-I regulation of apoptosis in SHEP cells exposed to high concentrations of mannitol could occur in several ways. IGF-I clearly prevents both caspase-3 activation and mitochondrial membrane depolarization in this system. These could be two independent events, or could act in concert as the prevention of caspase-3 cleavage by IGF-I could then block the depolarization of the mitochondrial membrane. IGF-I could also prevent the translocation of Bax to the mitochondria or cytochrome $c$ to the cytosol, which could prevent both caspase-3 cleavage and mitochondrial membrane depolarization. Short term activation of the IGF-IR could lead to protection of neuroblastoma cells by the $\mathrm{Pl}-3$ kinase-Akt phosphorylation of Bad as described in other cell systems, ${ }^{93,94}$ or as an uncharacterized Akt-independent pathway. A more long term effect of IGF-IR activation could be to stabilize or increase Bcl-2 protein expression, preventing a 'leaky' mitochondrial membrane thus allowing $\mathrm{Bcl}-2$ to exert its protective effect under apoptosis-inducing conditions. Finally, IGF-IR activation could allow for increased cell adhesion and the formation of aggregates, which can decrease the susceptibility of neuroblastoma cells to apoptosis. Further studies examining the effects of IGF-IR on apoptosis will help elucidate the role of the IGF-IR in neuroblastoma progression and survival.

\section{Materials and Methods}

\section{Materials}

Tissue culture plastic was purchased from Corning (Corning, NY, USA). Dulbecco's Modified Eagle's Medium (DMEM), calf serum (CS), Hank's Balanced Salt Solution (HBSS), and trypsin-EDTA were purchased from Gibco BRL (Gaithersburg, MD, USA). IGF-I was provided by Cephalon, Inc. (Westchester, PA, USA) and stored in $10 \mathrm{mM}$ acetic acid at $-80^{\circ} \mathrm{C}$. Caspase-3 polyclonal antibody was purchased from Pharmingen (San Diego, CA, USA), IGF-IR polyclonal antibody was purchased from Santa Cruz Biotechnology (Santa Cruz, CA, USA), and all other chemicals were purchased from Sigma Chemical Company (St. Louis, MO, USA). Bok-asp-fmk, a caspase inhibitor, was a kind gift from Dr. Brenda Shirer (Parke Davis Pharmaceuticals, Ann Arbor, MI 48109, USA).

\section{Cell culture}

SHEP human neuroblastoma cells were grown in DMEM+10\% CS at $37^{\circ} \mathrm{C}$ in a humidified atmosphere with $10 \% \quad \mathrm{CO}_{2}$. SHEP cells transfected with IGF-IR (SHEP/IGF-IR), ${ }^{13}$ SHEP cells transfected with bcl-2 (SHEP/Bcl-2), ${ }^{39}$ and SHEP cells transfected with the full length IGF-IR in the reverse orientation ${ }^{13}$ were maintained in $\mathrm{DMEM}+10 \% \mathrm{CS}+250 \mu \mathrm{g} / \mathrm{ml} \mathrm{G} 418$ (Gibco BRL). All cell types were routinely subcultured by removing cells from the plates with trypsinEDTA.

\section{Transfection of SHEP cells}

SHEP neuroblastoma cells were stably transfected with pSFFVneo/ rhIGF-IR (SHEP/IGF-IR cells), ${ }^{13}$ pSFFVneo/Bcl-2 (SHEP/Bcl-2 cells), ${ }^{39}$ or pSFFVneo with the full length IGF-IR in the reverse orientation $^{13}$ (FC-4 cells) using Lipofectin (Life Technologies, Inc., Gaithersburg, MD, USA) following manufacturer's instructions. Transfected cells were selected using $500 \mu \mathrm{g} / \mathrm{ml} \mathrm{G} 418$.

\section{Flow cytometry}

Analysis of DNA content was performed using flow cytometry. Cells were plated in 6 -well plates at $1 \times 10^{5} \mathrm{cells} / \mathrm{cm}^{2}$. After reaching near confluency, cells were serum deprived for $4 \mathrm{~h}$ and exposed to experimental conditions for the indicated times. Cells were removed from the plates with trypsin-EDTA, rinsed in HBSS, fixed in ice cold $70 \%$ ethanol, and stored at $4{ }^{\circ} \mathrm{C}$. Cells were stained $2-12 \mathrm{~h}$ with $18 \mu \mathrm{g} / \mathrm{ml}$ propidium iodide and $40 \mu \mathrm{g} / \mathrm{ml}$ RNase A at $4^{\circ} \mathrm{C}$. DNA content of propidium iodide stained cells was measured and separated into phases of the cell cycle based on the propidium iodide fluorescence. 
Per cent apoptotic cells in all cases was taken as per cent sub-g $g_{0}$ DNA as measured on an Epics Elite flow cytometry system (Coulter Cytometry, Hialeah, FL, USA). All results are expressed as the mean per cent apoptotic cells of three experiments \pm the standard error of the mean (S.E.M.).

\section{Western immunoblotting}

Western blot analyses were performed as previously described. ${ }^{40}$ Briefly, cell lysates were collected using RIPA buffer $(20 \mathrm{mM}$ Tris [pH 7.4], $150 \mathrm{mM} \mathrm{NaCl}, 1 \mathrm{mM}$ EDTA, $1 \mathrm{mM}$ EGTA, 0.1\% SDS, $1 \%$ sodium deoxycholate, $1 \%$ Triton $\mathrm{X}-100,1 \mathrm{mM}$ sodium orthovanadate, 0.1 trypsin inhibitor units $/ \mathrm{ml}, 10 \mu \mathrm{g} / \mathrm{ml}$ leupeptin, and $100 \mu \mathrm{g} / \mathrm{ml}$ PMSF). Seventy $\mu \mathrm{g}$ of protein were loaded and run on a $12.5 \%$ SDS-PAGE gel. After transfer to nitrocellulose membranes, the membranes were incubated with anti-caspase-3 antibody (Pharmingen, 1:1000) for $2 \mathrm{~h}$, anti-phospho-Akt (New England Biolabs, 1:1000) overnight, or antiphospho-Erk1/Erk2 antibody (New England Biolabs, 1:1000) overnight. All membranes were further incubated with horseradish peroxidase conjugated anti-rabbit secondary antibody (Santa Cruz Biotechnology, Santa Cruz, CA, USA; 1:2000 dilution) for $1 \mathrm{~h}$, developed with ECL (Amersham), and exposed to film (Hyperfilm-ECL, Amersham). Blots shown are one of three independent experiments performed.

\section{Bisbenzimide staining}

Cells were plated at $1 \times 10^{4}$ cells $/ \mathrm{cm}^{2}$ on glass coverslips and grown in $\mathrm{DMEM}+10 \% \mathrm{CS}$. Serum deprived cells were treated for $24 \mathrm{~h}$, fixed in $4 \%$ paraformaldehyde for $15 \mathrm{~min}$, rinsed in phosphate buffered saline (PBS), stained with $1 \mu \mathrm{g} / \mathrm{ml}$ bisbenzimide in PBS for $30 \mathrm{~min}$, then rinsed in PBS and mounted onto slides. Cells were viewed under ultraviolet illumination on a Leitz Orthoplan microscope.

\section{Caspase-3 fluorometric activity assay}

Near confluent cells were serum deprived for $4 \mathrm{~h}$, treated with $300 \mathrm{mM}$ mannitol, and harvested at the indicated times using trypsin-EDTA. The caspase-3 fluorometric activity assay was performed per instructions (Pharmingen, San Diego, CA, USA). Briefly, suspended cells were rinsed in PBS. Twenty $\mu \mathrm{g}$ of the DEVD-AMC substrate was added, and cells were incubated at $37^{\circ} \mathrm{C}$ for $1 \mathrm{~h}$. When caspase- 3 is activated, it cleaves the DEVD-AMC artificial substrate, causing an increase in fluorescence. The fluorescence was immediately analyzed by flow cytometry. Results are expressed as the change in fluorescence from control. Results are the mean+S.E.M. for three experiments performed.

\section{Measure of mitochondrial membrane potential}

Cells were treated for flow cytometry as described above. After $18 \mathrm{~h}$ of treatment, cells were exposed to $5 \mu \mathrm{g} / \mathrm{ml}$ Rhodamine 123 (Rh123), a mitochondrial specific dye, in HBSS for $30 \mathrm{~min}$ at $37^{\circ} \mathrm{C}$. Cells were then lifted from the plate with trypsin-EDTA, stained with propidium iodide as described above, and immediately analyzed by flow cytometry. Cells with a depolarized mitochondrial membrane have decreased Rh123 fluorescence. ${ }^{26}$ Results are expressed as per cent propidium iodide, excluding cells with Rh123 fluorescence below control levels. Results are the mean+S.E.M. for three independent experiments.

\section{Acknowledgements}

The authors thank Ms. Judy Boldt for expert secretarial assistance, Dr. James Russell and Dr. Catherine Delaney for helpful discussions and Mr. Michael Peacock and Dr. Hsin-Lin Cheng for figure preparation. This work was supported by $\mathrm{NCl}$ Cancer Biology Training Program Grant \#3 T32 CA09676 (to CM van Golen), NIH R01 CA69276 (to VP Castle), and NIH RO1 NS36778 and NIH RO1 NS38849 (to EL Feldman).

\section{References}

1. Castleberry RP (1997) Biology and treatment of neuroblastoma. Pediatr. Clin. North. Am. 44: 919-936

2. Brodeur GM, Maris JM, Yamashiro DJ, Hogarty MD and White PS (1997) Biology and genetics of human neuroblastomas. J. Pediatr. Hematol. Oncol. 19: 93-101

3. Cianfarani S and Rossi P (1997) Neuroblastoma and insulin-like growth factor system - New insights and clinical perspectives. Eur. J. Pediatr. 156: 256-261

4. Nakagawara A, Nakamura Y, Ikeda H, Hiwasa T, Kuida K, Su M, Zhao H, Cnaan A and Sakiyama S (1997) High levels of expression and nuclear localization of interleukin-1 $B$ converting enzyme (ICE) and CPP32 in favorable human neuroblastoma. Cancer Res. 57: 4578-4584

5. Gelbard HA, Boustany RM and Schor NF (1997) Apoptosis in development and disease of the nervous system. 2. Apoptosis in childhood neurologic disease. Pediatr. Neurol. 16: 93-97

6. Jones Jl and Clemmons DR (1995) Insulin-like growth factors and their binding proteins: Biological actions. Endocr. Rev. 16: 3-34

7. Rubin R and Baserga R (1995) Insulin-like growth factor-I receptor - Its role in cell proliferation, apoptosis, and tumorigenicity. Lab. Invest. 73: 311-331

8. Li S, Ferger A, Miura M and Baserga R (1994) Mitogenicity and transforming activity of the insulin-like growth factor-l receptor with mutations in the tyrosine kinase domain. J. Biol. Chem. 269: 32558-32564

9. Hongo A, D'Ambrosio C, Miura M, Morrione A and Baserga R (1996) Mutational analysis of the mitogenic and transforming activities of the insulin-like growth factor I receptor. Oncogene 12: 1231 - 1238

10. Surmacz E, Sell C, Swantek J, Kato H, Roberts CJ, LeRoith D and Baserga R (1995) Dissociation of mitogenesis and transforming activity by C-terminal truncation of the insulin-like growth factor-I receptor. Exp. Cell. Res. 218: 370 380

11. Li SW, Resnicoff M and Baserga R (1996) Effect of mutations at serines 1280 1283 on the mitogenic and transforming activities of the insulin-like growth factor receptor. J. Biol. Chem. 271: 12254-12260.

12. Miura M, Surmacz E, Burgaud J-L and Baserga R (1995) Different effects on mitogenesis and transformation of a mutation at tyrosine 1251 of the insulin-like growth factor I receptor. J. Biol. Chem. 270: 22639-22644

13. Singleton JR, Randolph AE and Feldman EL (1996) Insulin-like growth factor receptor prevents apoptosis and enhances neuroblastoma tumorigenesis. Cancer Res. 56: 4522-4529

14. Kim B, Cheng H-L, Margolis B and Feldman EL (1998) Insulin receptor substrate2 and Shc play different roles in insulin-like growth factor-I signaling. J. Biol. Chem. 273: 34543-34550

15. White M and Kahn CR (1994) The insulin signaling system. J. Biol. Chem. 269 $1-4$

16. Sun JS, Rothenburg P, Kahn CR, Backer JM, Aracki E, Wilden PA, Cahill DA Oldstein BJ and White MF (1991) Structure of the insulin receptor substrate IRS-1 defines a unique signal transduction protein. Nature 352: 73-77

17. Liu Q, Schacher D, Hurth C, Freund GG, Dantzer R and Kelley KW (1997) Activation of phosphatidylinositol 3 '-kinase by insulin-like growth factor-I rescues promyeloid cells from apoptosis and permits their differentiation into granulocytes. J. Immunol. 159: 829-837

18. Minshall C, Arkins S, Freund GG and Kelley KW (1996) Requirement for phosphatidylinositol 3 '-kinase to protect hemopoietic progenitors agains apoptosis depends upon the extracellular survival factor. J. Immunol. 156: 939-947

19. D'Mello SR, Borodezt K and Soltoff SP (1997) Insulin-like growth factor and potassium depolarization maintain neuronal survival by distinct pathways: Possible involvement of PI 3-kinase in IGF-1 signaling. J. Neurosci. 17: 1548 1560 
20. Miller TM, Tansey MG, Johnson Jr EM and Creedon DJ (1997) Inhibition of phosphatidylinositol 3-kinase activity blocks depolarization- and insulin-like growth factor I-mediated survival of cerebellar granule cells. J. Biol. Chem. 272: 9847-9853

21. Kulik G, Klippel A and Weber MJ (1997) Antiapoptotic signalling by the insulinlike growth factor I receptor, phosphatidylinositol 3-kinase, and Akt. Mol. Cell. Biol. 17: 1595-1606

22. Dudek H, Datta SR, Franke TF, Birnbaum MJ, Yao R, Cooper GM, Segal RA Kaplan DR and Greenberg ME (1997) Regulation of neuronal survival by the serine-threonine protein kinase Akt. Science 275: 661-665

23. Reed JC (1994) Bcl-2 and the regulation of programmed cell death. J. Cell. Biol. 124: $1-6$

24. Jacobson MD and Evan GI (1994) Breaking the ice. Structural and functional similarities have been discovered between two mammalian proteins, $\mathrm{Bcl}-2$ and interleukin $1 \beta$-converting enzyme, and proteins encoded by nematode cell-death genes. Curr. Biol. 4: 337-340

25. Schendel SL, Xie Z, Montal MO, Matsuyama S, Montal M and Reed JC (1997) Channel formation by antiapoptotic protein Bcl-2. Proc. Natl. Acad. Sci. USA 94 5113-5118

26. Vander Heiden MG, Chandel NS, Williamson EK, Schumacker PT and Thompson CB (1997) Bcl-xl regulates the membrane potential and volume homeostasis of mitochondria. Cell 91: 627-637

27. Minn AJ, Velez P, Schendel SL, Liang H, Muchmore SW, Fesik SW, Fill M and Thompson CB (1997) Bcl-x forms an ion channel in synthetic lipid membranes. Nature 385: 353-357

28. Reed JC, Meister L, Tanaka S, Cuddy M, Yum S, Geyer C and Pleasure D (1991) Differential expression of $b c / 2$ protooncogene in neuroblastoma and other human tumor cell lines of neural origin. Cancer Res. 51: 6529-6538

29. Dole MG, Jasty R, Cooper MJ, Thompson CB, Nunez G and Castle VP (1995) $\mathrm{Bcl}-\mathrm{x}_{\mathrm{L}}$ is expressed in neuroblastoma cells and modulates chemotherapyinduced apoptosis. Cancer Res. 55: 2576-2582

30. Singleton JR, Dixit VM and Feldman EL (1996) Type I insulin-like growth factor receptor activation regulates apoptotic proteins. J. Biol. Chem. 271: 31791 31794

31. Alnemri ES, Livingston DJ, Nicholson DW, Salvesen G, Thornberry NA, Wong WW and Yuan J (1996) Human ICE/CED-3 protease nomenclature. Cell 87: 171

32. Villa P, Kaufmann SH, Earnshaw WC (1997) Caspases and caspase inhibitors. Trends Biochem. Sci. 22: 388-393

33. Tewari M and Dixit VM (1995) Fas- and tumor necrosis factor-induced apoptosis is inhibited by the poxvirus crmA gene product. J. Biol. Chem. 270: 3255-3260

34. Chinnaiyan AM, O'Rourke K, Tewari M and Dixit VM (1995) FADD, a novel death domain-containing protein, interacts with the death domain of Fas and initiates apoptosis. Cell 81: 505-512

35. Tewari M, Beidler DR and Dixit VM (1995) CrmA-inhibitable cleavage of the 70 $\mathrm{kDa}$ protein component of the $\mathrm{U} 1 \mathrm{small}$ nuclear ribonucleoprotein during fas-and tumor necrosis factor-induced apoptosis. J. Biol. Chem. 270: 18738-18741

36. Janicke RU, Sprengart ML, Wati MR and Porter AG (1998)Caspase-3 is required for DNA fragmentation and morphological changes associated with apoptosis. J. Biol. Chem. 273: 9357-9360

37. Woo M, Hakem R, Soengas MS, Duncan GS, Shahinian A, Kagi D, Hakem A McCurrach M, Khoo W, Kaufman SA, Senaldi G, Howard T, Lowe SW and Mak TW (1998) Essential contribution of caspase 3/CPP32 to apoptosis and its associated nuclear changes. Genes Dev. 12: 806-819

38. van Golen CM and Feldman EL (2000) Insulin-like growth factor I is the key growth factor in serum that protects neuroblastoma cells from hyperosmoticinduced apoptosis. J. Cell Physiol. 182: 24-32

39. Dole M, Nunez G, Merchant AK, Maybaum J, Rode CK, Bloch CA and Castle VP (1994) Bcl-2 inhibits chemotherapy-induced apoptosis in neuroblastoma. Cancer Res. 54: 3253-3259

40. Leventhal PS, Randolph AE, Vesbit TE, Schenone A, Windebank AJ and Feldman EL (1995) Insulin-like growth factor-Il as a paracrine growth factor in human neuroblastoma cells. Exp. Cell. Res. 221: 179-186

41. Biedler JL, SpenglerBA, Tien-ding C and Ross RA (1988) Transdifferentiation of human neuroblastoma cells results in coordinate loss of neuronal and malignant properties. Adv. Neuroblastoma Res. 2: 265-276

42. Reed JC (1997) Double identity for proteins of the Bcl-2 family. Nature 387: 773 776
43. Marzo I, Brenner C, Zamzami N, Susin SA, Beutner G, Brdiczka D, Remy R, Xie ZH, Reed JC and Kroemer G (1998) The permeability transition pore complex: a target for apoptosis regulation by caspases and bcl-2-related proteins. J. Exp. Med. 187: $1261-1271$

44. Kroemer G, Dallaporta B and Resche-Rigon M (1998) The mitochondrial death/ life regulator in apoptosis and necrosis. Annu. Rev. Physiol. 60: 619-642

45. Macaulay VM (1992) Insulin-like growth factors and cancer. Br. J. Cancer 65: 311-320

46. Quinn KA, Treston AM, Unsworth EJ, Miller MJ, Vos M, Grimley C, Battey J, Mulshine JL and Cuttitta F (1996) Insulin-like growth factor expression in human cancer cell lines. J. Biol. Chem. 271: 11477-11483

47. Matthews CC, Odeh H and Feldman EL (1997) Insulin-like growth factor-I is an osmoprotectant in human neuroblastoma cells. Neuroscience 79: 525-534

48. Werner H and Le Roith D (1997) The insulin-like growth factor-I receptor signaling pathways are important for tumorigenesis and inhibition of apoptosis. Crit. Rev. Oncog. 8: 71-92

49. Resnicoff M, Abraham D, YutanawiboonchaiW, Rotman HL, Kajstura J, Rubin R, Zoltick $P$ and Baserga R (1995) The insulin-like growth factor I receptor protects tumor cells from apoptosis in vivo. Cancer Res. 55: 2463-2469

50. Resnicoff M, Sell C, Rubini M, Coppola D, Ambrose D, Baserga R and Rubin R (1994) Rat glioblastoma cells expressing an antisense RNA to the insulin-like growth factor-1 (IGF-1) receptor are nontumorigenic and induce regression of wild-type tumors. Cancer Res. 54: 2218-2222

51. Ambrose D, Resnicoff M, Coppola D, SellC, Miura M, JamesonS, Baserga Rand Rubin R (1994) Growth regulation of human glioblastoma T98G cells by insulinlike growth factor-1 and its receptor. J. Cell Physiol. 159: 92-100

52. Prager D, Li H-L, Asa S and Melmed S (1994) Dominant negative inhibition of tumorigenesis in vivo by human insulin-like growth factor I receptor mutant. Proc. Natl. Acad. Sci. USA 91: $2181-2185$

53. Kaleko M, Rutter WJ and Miller AD (1900) Overexpression of the human insulinlike growth factor I receptor promotes ligand-dependent neoplastic transformation. Mol. Cell. Biol. 10: 464-473

54. Sell C, Baserga R and Rubin R (1995) Insulin-like growth factor I (IGF-I) and the IGF-I receptor prevent etoposide-induced apoptosis. Cancer Res. 55: 303-306

55. Baserga R (1994) Oncogenes and the strategy of growth factors. Cell 79: $927-$ 930

56. Kuida K, Haydar TF, Kuan CY, GuY, Taya C, Karasuyama H, Su MS, Rakic P and Flavell RA (1998) Reduced apoptosis and cytochrome-c mediated caspase activation in mice lacking caspase 9. Cell 94: 325-337

57. Kim B, Leventhal PS and Feldman EL (1996) Insulin-like growth factor-I (IGF-I) induces localization of RAC and phosphatidylinositol 3-kinase (PI3-K) to membrane ruffles. Mol. Biol. Cell. 7: 342a (Abstract)

58. Dunn SE, Hardman RA, Kari FW and BarrettJC (1997) Insulin-like growth factor I (IGF-I) alters drug sensitivity of HBL100 human breast cancer cells by inhibition of apoptosis induced by diverse anticancer drugs. Cancer Res. 57: 2687-2693

59. Guo YS, Jin GF, Houston CW, Thompson JC and Townsend Jr CM (1998) Insulin-like growth factor-I promotes multidrug resistance in MCLM colon cancer cells. J. Cell Physiol. 175: 141-148

60. Lamm GM and Christofori G (1998) Impairment of survival factor function potentiates chemotherapy-induced apoptosis in tumor cells. Cancer Res. 58: 801-807

61. Skaper SD, Floreani M, Negro A, Facci L and Giusti P (1998) Neurotrophins rescue cerebellar granule neurons from oxidative stress-mediated apoptotic death: selective involvement of phosphatidylinositol 3-kinase and the mitogenactivated protein kinase pathway. J. Neurochem. 70: 1859-1868

62. Eldadah BA, Yakovlev AG and Faden AI (1997) The role of CED-3-related cysteine proteases in apoptosis of cerebellar granule cells. J. Neurosci. 17: 6105-6113

63. Rivera S, Guillot S, Agassandian C, Ben Ari Y and Khrestchatisky M (1998) Serum deprivation-induced apoptosis in cultured hippocampi is prevented by kainate. Neuroreport 9: 3949-3953

64. Yano S, Tokumitsu H and Soderling TR (1998) Calcium promotes cell survival through CaM-K kinase activation of the protein-kinase-B pathway. Nature 396 : $584-587$

65. Solovyan V, Bezvenyuk Z, Huotari V, Tapiola T, Suuronen T and Salminen A (1998) Distinct mode of apoptosis induced by genotoxic agent etoposide and serum withdrawal in neuroblastoma cells. Brain Res. Mol. Brain Res. 62: 43-55 
66. Bozzo C, Bellomo G, Silengo L, Tarone G and Altruda F (1997) Soluble integrin ligands and growth factors independently rescue neuroblastoma cells from apoptosis under nonadherent conditions. Exp. Cell. Res. 237: 326-337

67. Wang L, Ma W, Markovich R, Lee WL and Wang PH (1998) Insulin-like growth factor I modulates induction of apoptotic signaling in $\mathrm{H} 9 \mathrm{C} 2$ cardiac muscle cells. Endocrinology 139: 1354-1360

68. Parrizas M, Saltiel AR and LeRoith D (1997) Insulin-like growth factor 1 inhibits apoptosis using the phosphatidylinositol 3 '-kinase and mitogen-activated protein kinase pathways. J. Biol. Chem. 272: 154-161

69. Russell JW, Windebank AJ, Schenone A and Feldman EL (1998) Insulin-like growth factor-I prevents apoptosis in neurons after nerve growth factor withdrawal. J. Neurobiol. 36: 455-467

70. Posmantur R, McGinnis K, Nadimpalli R, Gilbertsen RB and Wang KKW (1997) Characterization of CPP32-like protease activity following apoptotic challenge in SH-SY5Y neuroblastoma cells. J. Neurochem. 68: 2328-2337

71. Uehara T, Kikuchi $Y$ and Nomura $Y$ (1999) Caspase activation accompanying cytochrome $\mathrm{C}$ release from mitochondria is possibly involved in nitric oxideinduced neuronal apoptosis in SH-SY5Y cells. J. Neurochem. 72: 196-205

72. Nath R, Probert Jr A, McGinnis KM and Wang KK (1998) Evidence for activation of caspase-3-like protease in excitotoxin- and hypoxia/hypoglycemia-injured neurons. J. Neurochem. 71: 186-195

73. Werner H(1998) Dysregulation of the type 1 IGF receptor as a paradigm in tumor progression. Mol. Cell. Endocrinol. 141: 1-5

74. Resnik JL, Reichart DB, Huey K, Webster NJ and Seely BL (1998) Elevated insulin-like growth factor I receptor autophosphorylation and kinase activity in human breast cancer. Cancer Res. 58: 1159-1164

75. Liu X, Turbyville T, Fritz A and Whitesell L (1998) Inhibition of insulin-like growth factor I receptor expression in neuroblastoma cells induces the regression of established tumors in mice. Cancer Res. 58: 5432-5438

76. Boyle CC and Hickman JA (1997) Toxin-induced increase in survival factor receptors: modulation of the threshold for apoptosis. Cancer Res. 57: 24042409

77. Li Q, Li B, Wang X, Leri A, Jana KP, Liu Y, Kajstura J, Baserga R and Anversa P (1997) Overexpression of insulin-like growth factor-1 in mice protects from myocyte death after infarction, attenuating ventricular dilation, wall stress, and cardiac hypertrophy. J. Clin. Invest. 100: 1991-1999

78. Guvakova MA and Surmacz E (1997) Overexpressed IGF-I receptors reduce estrogen growth requirements, enhance survival, and promote E-cadherinmediated cell-cell adhesion in human breast cancer cells. Exp. Cell. Res. 231: $149-162$

79. Reed JC, Miyashita T, Takayama S, Wang H-G, Sato T, Krajewski S, AimeSempe C, Bodrog S, Kitada S and Hanada M (1996) Bcl-2 family proteins: regulators of cell death involved in the pathogenesis of cancer and resistance to therapy. J. Cell. Biol. 60: 23-32

80. Merry DE and Korsmeyer SJ (1997) Bcl-2 gene family in the nervous system. Annu. Rev. Neurosci. 20: 245-267
81. Srinivasan A, FosterLM, Testa MP, Ord T, Keane RW, Bredesen DE and Kayalar C (1996) Bcl-2 expression in neural cells blocks activation of ICE/CED-3 family proteases during apoptosis. J. Neurosci. 16: 5654-5660

82. Bonnotte B, Favre N, Moutet M, Fromentin A, Solary E, Martin M and Martin F (1998) Bcl-2-mediated inhibition of apoptosis prevents immunogenicity and restores tumorigenicity of spontaneously regressive tumors. J. Immunol. 161: $1433-1438$

83. Kluck RM, Bossy-Wetzel E, Green DR and Newmeyer DD (1997) The release of cytochrome c from mitochondria: a primary site for $\mathrm{Bcl}-2$ regulation of apoptosis. Science 275: $1132-1136$

84. Yang J, Liu X, Bhalla K, Kim CN, Ibrado AM, Cai J, Peng T-I, Jones DP and Wang $X$ (1997) Prevention of apoptosis by Bcl-2: Release of cytochrome c from mitochondria blocked. Science 275: 1129-1132

85. Fulda S, Susin SA, Kroemer G and Debatin K-M (1998) Molecular ordering of apoptosis induced by anticancer drugs in neuroblastoma cells. Cancer Res. 58: 4453-4460

86. Samali A, Cai J, Zhivotovsky B, Jones DP and Orrenius S (1999) Presence of a pre-apoptotic complex of pro-caspase-3, Hsp60 and $\mathrm{Hsp} 10$ in the mitochondrial fraction of jurkat cells. EMBO J. 18: 2040-2048

87. Bossy-WetzelE, NewmeyerDD and Green DR(1998) Mitochondrial cytochrome c release in apoptosis occurs upstream of DEVD-specific caspase activation and independently of mitochondrial transmembrane depolarization. EMBO J. 17: $37-49$

88. McGinnis KM, Gnegy ME and Wang KK (1999) Endogenous bax translocation in SH-SY5Y human neuroblastoma cells and cerebellar granule neurons undergoing apoptosis. J. Neurochem. 72: 1899-1906

89. Eskes R, Antonsson B, Osen-Sand A, Montessuit S, Richter C, Sadoul R, Mazzei G, Nichols A and Martinou JC (1998) Bax-induced cytochrome C release from mitochondria is independent of the permeability transition pore but highly dependent on Mg2+ ions. J. Cell. Biol. 143: 217-224

90. Jurgensmeier JM, XieZ, Deveraux Q, Ellerby L, Bredesen D and Reed JC (1998) Bax directly induces release of cytochrome $\mathrm{c}$ from isolated mitochondria. Proc. Natl. Acad. Sci. USA 95: 4997-5002

91. Kluck RM, Bossy-Wetzel E, Green DR and Newmeyer DD (1997) The release of cytochrome $\mathrm{c}$ from mitochondria: a primary site for $\mathrm{Bcl}-2$ regulation of apoptosis [see comments]. Science 275: 1132-1136

92. Cosulich SC, Savory PJ and Clarke PR (1999) Bcl-2 regulates amplification of caspase activation by cytochrome c. Curr. Biol. 9: 147-150

93. del Peso L, Gonzalez-Garcia M, Page C, Herrera R and Nunez G (1997) Interleukin-3-induced phosphorylation of BAD through the protein kinase Akt. Science 278: $687-689$

94. Datta SR, Dudek H, Tao X, Masters S, Fu H, Gotoh Y and Greenberg ME (1997) Akt phosphorylation of BAD couples survival signals to the cell-intrinsic death machinery. Cell 91: 231-241 